\title{
SUGGESTING A NEW MANAGEMENT INFORMATION SYSTEMS EDUCATION PROGRAMME FOR KNOWLEDGE SOCIETY: IMPLICATIONS FROM TURKISH CASE
}

\author{
Tunç Durmuş Medeni ${ }^{1}$ and İhsan Tolga Medeni ${ }^{\star}$ \\ ${ }^{1}$ Asst. Prof. Dr., Ankara Yıldırım Beyazıt University, Turkey, tuncmedeni@ybu.edu.tr \\ ${ }^{2}$ Asst. Prof. Dr., Ankara Yıldırım Beyazıt University, Turkey, tolgamedeni@ybu.edu.tr \\ ${ }^{*}$ Corresponding author
}

\begin{abstract}
In this work, we have developed a proposal for a new knowledge-based and practice-oriented MIS training programme for Knowledge Society (Strategy), adaptable to general undergraduate and graduate programme levels. In addition to these macro level recommendations and assessments, further micro level suggestions on specific course design and delivery have also been provided, benefiting from related reflective and refractive learning and knowledge management works.
\end{abstract}

Keywords: Educational Programme Design, Knowledge Society, Management Information Systems (MIS).

\section{INTRODUCTION}

Turkey has recently announced its new Information/Knowledge Society (KS) Strategy, which has specific actions for improving Information and Communication Technologies (ICT) education, research and entrepreneurial programmes in universities (See Appendix I: for instance, among other interrelated actions, actions \# 22, 24, 27, 28, 57, 72, Ministry of Development 2014).

As a recently-founded state university that provides MIS (Management Information Systems) undergraduate and graduate programmes, Yıldırım Beyazıt University (YBU), Business School (BS), Department of Management Information Systems) encourages innovation in its MIS programme and curriculum design, on the "transition from foundation to institutionalization phase" (quoted from former Dean, Prof. Mehmet Barca, in the Faculty Meeting at the beginning of 2015-2016 Autumn Academic Term).

Currently, providing one undergraduate programme and two graduate programme (one with and the other one without thesis), the MIS department is challenged by setting and sustaining a balance among different demands from potential and actual students, members of the academic community and administration. While currently-third-year students at the undergraduate level exhibit increasing worries about the possible career 
opportunities, the lack of motivation and commitment of students at all grades becomes worrisome among the faculty members. The scarcity of academic staff with necessary ICT competencies to deliver technical courses puts enormous pressure especially on the existing academic members. Various administrative requirements demands and issues also increase the burdens on the shoulders' of the staff.

All these recent developments and issues demand and provide a suitable basis for a proposal of a new MIS programme. In the next section, the basic literature sources and main steps for the development of this proposal will be provided.

\section{LITERATURE REVIEW AND MAIN STEPS OF PROPOSAL DEVELOPMENT}

For this proposal, initially the below main sources of information are used: i) Lauden \& Lauden's Information Systems Framework (2012) that consist of Management, Technology and Organizations, and ii) Coauthors' previous works on a practical knowledge-typology-based modular curriculum design for educating knowledge engineers (Medeni 2008a, Table 1 and Appendix II), as well as their various works on developing a working model for management education and a sample curriculum design for e-government education based upon the related paradigms (for example, Medeni et al, 2009 and Medeni\&Medeni, 2012). Benefiting from these sources, basic structure for a new knowledge-based and practice-oriented MIS programme for KS can be proposed (Figure 1).

Table 1. A Proposed Curriculum for Knowledge Engineering based upon Knowledge Typology based on Medeni (2008a)

\begin{tabular}{|c|c|c|c|}
\hline Courses & \multicolumn{3}{|l|}{ Lectures } \\
\hline $\begin{array}{l}\text { Generic } \\
\text { Courses }\end{array}$ & & & $\begin{array}{l}\text { Calculus, Statistics, } \\
\text { Algorithms, Engineering } \\
\text { Mathematics, Linear Algebra }\end{array}$ \\
\hline \multirow[t]{6}{*}{$\begin{array}{l}\text { Specialized } \\
\text { Courses }\end{array}$} & \multirow[t]{2}{*}{ Data } & $\begin{array}{l}\text { Computer Science } \\
\text { and Engineering }\end{array}$ & $\begin{array}{l}\text { Introduction to Programming, } \\
\text { Programming Languages, } \\
\text { Data Structure and File } \\
\text { Management, Computer } \\
\text { Organization and Operating } \\
\text { Systems, Database } \\
\text { Programming, Management } \\
\text { Information Systems, } \\
\text { Database Management } \\
\text { Systems, Data } \\
\text { Communications }\end{array}$ \\
\hline & & $\begin{array}{l}\text { Business and } \\
\text { Management }\end{array}$ & $\begin{array}{l}\text { Business Communication, } \\
\text { Organizational Theory, } \\
\text { Introduction to Business, } \\
\text { Engineering Management, } \\
\text { Human Resource } \\
\text { Management, Operations } \\
\text { Research, Accounting }\end{array}$ \\
\hline & \multirow[t]{2}{*}{ Information } & $\begin{array}{l}\text { Computer Science } \\
\text { and Engineering }\end{array}$ & $\begin{array}{l}\text { Computer Networks, Data } \\
\text { Security, Web Programming, } \\
\text { Information System Analysis } \\
\text { and Design, UML }\end{array}$ \\
\hline & & $\begin{array}{l}\text { Business and } \\
\text { Management }\end{array}$ & $\begin{array}{l}\text { Production and Operations } \\
\text { Management in IT Firms, } \\
\text { Finance }\end{array}$ \\
\hline & \multirow[t]{2}{*}{ Knowledge } & $\begin{array}{l}\text { Computer Science } \\
\text { and Engineering }\end{array}$ & $\begin{array}{l}\text { Decision Support Systems, } \\
\text { AI, Expert Systems, Data } \\
\text { Mining }\end{array}$ \\
\hline & & $\begin{array}{l}\text { Business and } \\
\text { Management }\end{array}$ & $\begin{array}{l}\text { Forecasting in Business, } \\
\text { Knowledge Management }\end{array}$ \\
\hline
\end{tabular}




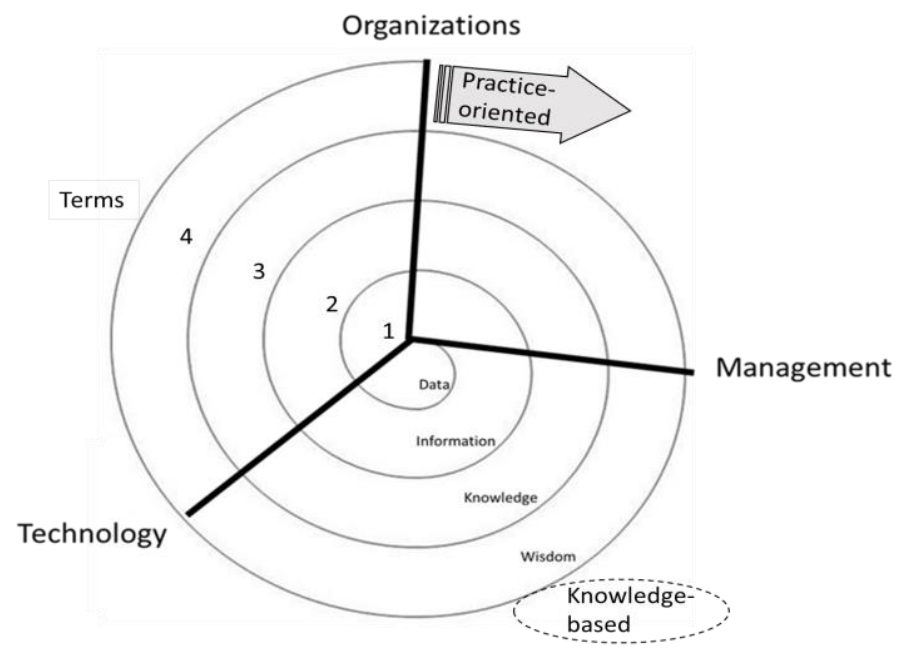

Fig. 1. Proposal for knowledge-based practice-oriented MIS programme structure for KS

The suggested structure adapts the trivet domains of Management, Technology and Organizations and allocates courses for each based upon different levels of knowledge typology, where

- data stands for foundation common or preparation courses,

- information stands for faculty instructed common, public and explicit information built on this foundation,

- knowledge stands for personally learned private, tacit knowledge based on interest and expertise build on the informative courses,

- wisdom stands for experience on top of all.

This structure is adaptable to undergraduate and graduate programmes in general; the only difference can be the interpretation of the academic term related to the grades, i.e. in undergraduate programme the terms can be either freshman, junior, sophomore or senior year, whereas in the graduate programme it can be either spring or autumn period, which may not make much difference in YBÜ, as in undergraduate programmes in Business Administration Faculty, most of the departmental courses are allocated to the last two years. While the initial period is dedicated to foundation courses, the second term focuses on must courses that mostly instruct public information and the third term on must and elective courses that develop personal knowledge. The final and the fourth term is then dedicated to project, thesis or internship that integrates all Management, Technology and Organizations aspects into one main knowledge-based work for practical impact. The resulting model of MIS knowledge-based society and practice-oriented programme, called "lolipop" model, originally developed in this paper, is illustrated in detail below (Figure 2)

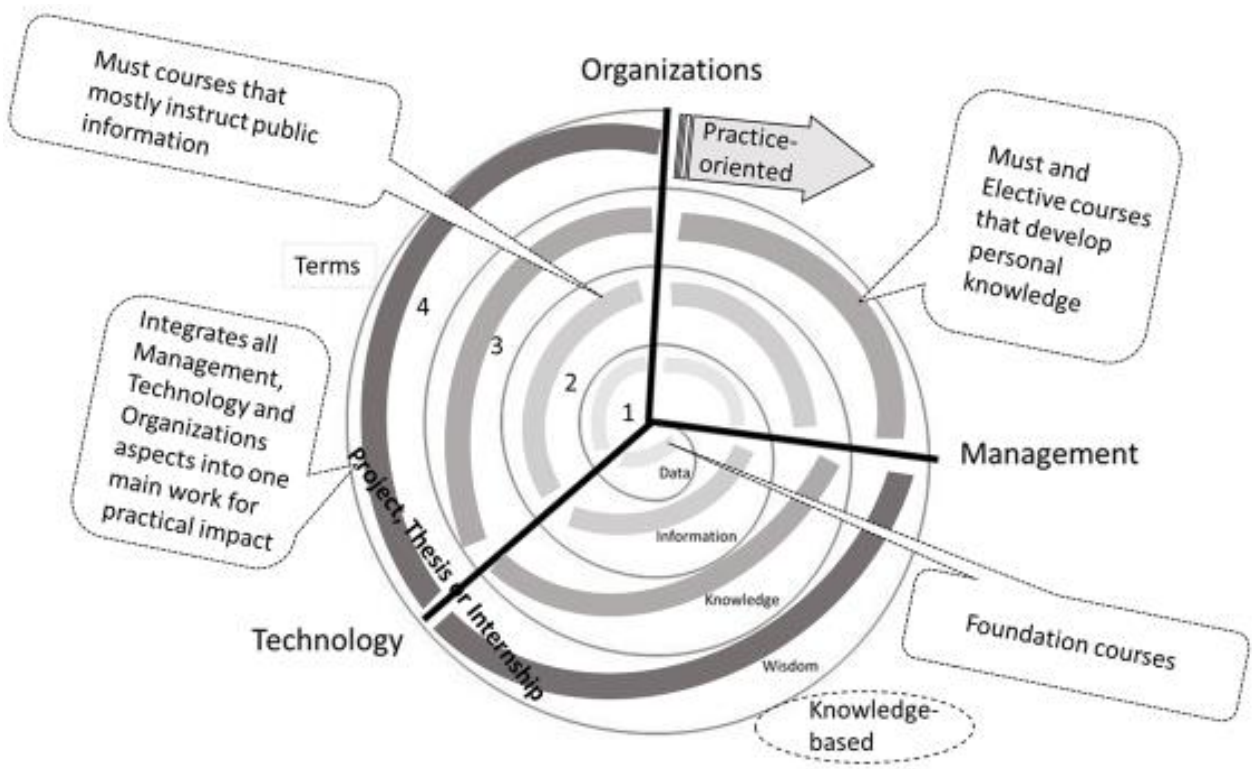

Fig. 2. "lolipop" model for MIS knowledge-based society and practice-oriented programme 
A key aspect of the suggested structure is its practice-orientation that is crucial for improving learning outcomes and transferring them into workplace and real practice. Conceptual models of experiential learning (Kolb\&Rubin, 1991) and experienced reflection (Mintzberg, 2005), as well as refraction (Medeni, 2008b) can support the realization of this orientation, bridging learning/knowing/theory and practice/experiencing/reality.

Accordingly a specific course design can be suggested as below (Figure 3):

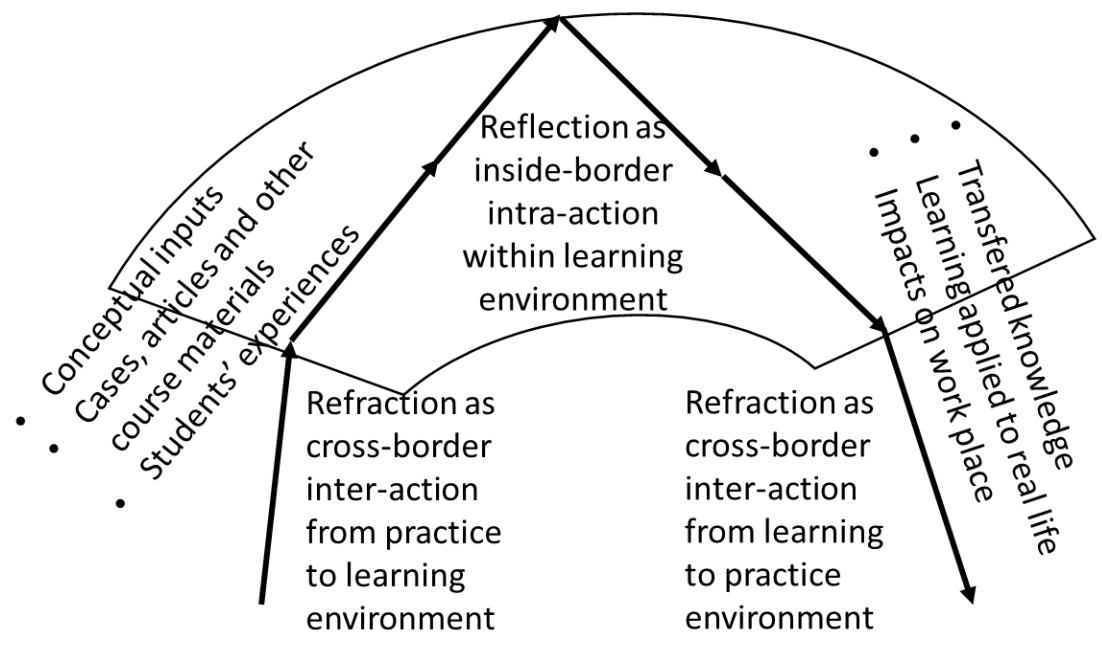

Fig. 3. Suggestion for reflective and refractive course design within the lolipop model

Here refraction complements reflection to link practice and education, i.e. refraction is conceptualized as cross-border inter-action between practice and learning environments, whereas reflection is interpreted as inside-border intra-action within the learning (or practice) environment, metaphorically tying natural (physics and optics) and social (learning and knowledge management) phenomena. Such reflective and refractive design requests adaptation of learning inputs, processes and outputs/outcomes (Medeni, 2008b). For instance, conceptual input as existing literature or theoretical models within lectures or seminars can be provided by not only faculty members but also students involved in their own learning as active participants. Cases, articles and other course materials are complemented by students' experiences from both before and outside education, but also during and inside education, while participating in the class activities or experimenting with class outcomes. Benefiting from the reflective environment of the school, students can develop their own working-models, define problems in their workplace and take action to address them. As a consequence, learning outcomes can also be refracted into the real life practice in the forms of transferable knowledge, applied learning and tangible impacts. Education institutionally should support this reflective and refractive learning for the purpose of practical benefit. It is important to provide such occasions that facilitate active participation of students, including concept development, problem definition and solving as well. Accordingly faculty members should also adapt their roles and responsibilities, moving beyond merely instructing inside classroom to be more actively and collaboratively involved with students' institutions.

All these aspects related with knowledge, knowing and learning can actually be considered a fourth domain that supports the Management, Technology and Organization trivet domains for the development of this knowledge-based and practice-oriented MIS programme design. For the sake of distinguishing it from the Knowledge Term in term 3, we can call this domain Knowing \& Learning.

\section{CONCLUSIONS}

The first three terms benefit from these conceptual designs and models have been built upon the practiceorientation, reflective and refractive link between educational programme and practice within a more general perspective of learning and knowledge management. As a result, benefiting from both existing list of courses allocated for each term and newly-suggested courses to fill the gaps, the Management, Technology, Organizations and Knowing \& Learning domains can be populated with respective courses in undergraduate and graduate programmes, including an Electives-pool (Table 2). For instance, Programming or Database related courses can populate Data-Technology cell, Information Networks and Information Security can populate Information-Technology cell, Decision Support Systems and Artificial Intelligence related courses can populate Knowledge-Technology cell in all programmes. Seminar and Academic Specialization courses in Graduate programme with Thesis can also populate Knowledge-Knowing \& Learning cell. E-Learning 
Systems, or in collaboration with Knowledge and Documentation Management department in YBU Humanities and Social Sciences Faculty, for instance, Information Resources and Information Access Systems can also be suggested to populate Information-Knowledge \& Learning cell in the graduate nonthesis programme. This model needs to be applied into practice, and the resulting outputs and outcomes (such as number of alumni who works on jobs in related fields and sectors) should be observed to evaluate the changes and its benefits. Accordingly, a monitoring and evaluation mechanism can also be proposed in the future studies.

Table 2: An exemplary table for populating domain-specific courses for each knowledge-based term to be used for each programme separately

\begin{tabular}{|c|c|c|c|c|}
\hline $\begin{array}{r}\text { UNDERGRADUATE } \\
\text { GRADUATE- THESIS } \\
\text { GRADUATE- } \\
\text { NONTHESIS }\end{array}$ & Management & Technology & Organizations & $\begin{array}{l}\text { Knowing } \\
\text { \& Learning }\end{array}$ \\
\hline $\begin{array}{r}\text { Term1, Data-based } \\
\text { courses }\end{array}$ & $\begin{array}{l}\text { Introduction to } \\
\text { Business }\end{array}$ & $\begin{array}{l}\text { Database } \\
\text { Management Systems }\end{array}$ & Organizational Theory & $\begin{array}{l}\text { Data Structures } \\
\text { and Algorithms }\end{array}$ \\
\hline $\begin{array}{r}\text { Term2, Information- } \\
\text { based courses }\end{array}$ & Operations Research & $\begin{array}{l}\text { Data Mining and } \\
\text { Information Retrieval }\end{array}$ & $\begin{array}{l}\text { Management } \\
\text { Information Systems }\end{array}$ & $\begin{array}{l}\text { Information } \\
\text { Systems Analysis } \\
\text { and Design }\end{array}$ \\
\hline $\begin{array}{r}\text { Term3, Knowledge- } \\
\text { based courses }\end{array}$ & $\begin{array}{l}\text { Forecasting in } \\
\text { Business }\end{array}$ & $\begin{array}{l}\text { Business Intelligence } \\
\text { and Data Support } \\
\text { Systems }\end{array}$ & $\begin{array}{l}\text { Knowledge } \\
\text { Visualization and } \\
\text { Knowledge Mapping }\end{array}$ & $\begin{array}{l}\text { Knowledge } \\
\text { Management }\end{array}$ \\
\hline
\end{tabular}

As mostly visible in the integrative wisdom phase, the fourth terms, in addition to improving learning outcomes and transferring them into workplace and real practice, the suggested programme model and course structure can also prove to be mostly useful for positioning the school offerings with respect to the all Knowledge Society Strategy actions introduced above. The fourth term integrative work can specifically facilitate university students' working in private sector and enforcing graduation projects to be completed by students' working in companies. For graduate programme, these private sector companies can be the institutions that students are affiliated with. Even the academic master thesis or doctorate dissertation work should have this practice-orientation, applying proper research methodologies such as Action Research.

These collaborative interactions with private sector can also pave the way for more formal collaborations in the form of co-research centers or cluster-linked accelerator centers for Internet enterprises in YBU, as aimed by other actions $(\# 24,57)$ of the Strategy. University students and academicians can work as entrepreneurs or staff in these centers, providing new opportunities for all concerned. Meanwhile, the Faculty members will benefit from continuous interaction with industry, giving them the state-of-the-art to be kept updated with recent developments in reality, and engage in interdisciplinary leading-edge work (that can also result in a digital library and journal), contributing to the satisfaction of the objectives recommended in actions 27 and 72. Here, collaborative interactions with other faculties and departments of YBU such as Computer Engineering or Knowledge and Document Management can be also very important.

In this work, we have developed a proposal for a new knowledge-based and practice-oriented MIS programme for Knowledge Society (Strategy), adaptable to general undergraduate and graduate programme levels. In addition to these macro level recommendations and assessments, more micro level suggestions on specific course design and delivery has also been provided, benefiting from related reflective and refractive learning and knowledge management works. A tangible outcome of this work is a specific programme design to be proposed to YBU MIS department in order to improve learning effectiveness and position itself with respect to new Knowledge Society Strategy implementation. Accordingly, these suggestions in the form of programme structure, course and curriculum design can also be adapted or used as an example by other relevant and interested institutions in Turkey and other countries that also aim to improve their programmes. For instance, first for the graduate programmes YBU MIS department members including the co-authors, or next for other ICT-related education and training programmes these other KS institutions can consider populating the specific knowledge-based terms with domain-specific courses in Management, Technology, Organizations, as well as complementary Knowing \& Learning.

\section{ACKNOWLEDGEMENT}

Thank you for MIS Department for inspiring and encouraging us to prepare this work, which, we hope, contributes to the improvement of our departmental work. Also we acknowledge the collegial contributions 
from members of YBU BS for the improvement of the initial draft, thanks to the seminar (MIS Research Seminar Series) given on 24th of December, 2015.

The preliminary proceeding was presented in INTCESS 2016, with the financial support of Ankara Yildirim Beyazit University BAP department's BEKP program.

\section{REFERENCE LIST}

Laudon, K. C., Laudon, J. P. (2012). Management information systems: Managing the digital firm. Toronto: Prentice Hall. 12th Edition

Medeni, I. T (2008a) Knowledge Engineering and a Proposed Currıculum. Unpublished Master's Thesis submitted to Çankaya University (available online at YOKSIS Database)

Medeni, T.D. (2008b) Educating Managers for the Global Knowledge Economy: An Action Research into International Master Program in Practicing Management doctorate thesis submitted to JAIST, Japan

Medeni, T.D. \& Medeni, I.T. (2012) Reflection And Refraction for Knowledge Management Systems International Journal on eGovernment and eBusiness Studies Vol 4, No 1, 2012 ISSN: 2146-0744 (available online at SOBIAD IJEBEG Database)

Medeni, I.T., Sağsan, M., Medeni, T., Balcı, A., Taşkaya, M. (2009) Developing an e-government education programme curriculum based on knowledge management paradigms to support institutional transformation. International Journal on eGovernment and eBusiness Studies, (I):2, pp. 35-47 (available online at SOBIAD IJEBEG Database)

Ministry of Development (2014) Information Society Strategy and Action Plan (available online at Kalkınma Bakanlığı and Bilgi Toplumu sites)

Mintzberg, H. (2005). Managers not MBAs: A hard look at the soft practice of managing and management development. San Francisco, CA: Berrett-Koehler Pub.

YBU and YBU BS MIS Department Official Websites as of 2015, http://ybu.edu.tr/, and http://ybusm.org/index.php?title=Department of Management Information Systems

\section{APPENDIX I, KS STRATEGY ACTIONS}

- 22. Updating ICT Curriculum in universities action will develop undergraduate and graduate programs in ICT related fields.

- 24. Developing ICT education/training collaboration programme among private sector and education institutions action will encourage university students' working part-time in private sector, adjusting the legislation to enforce graduation projects to be completed by students' working in companies. It also will support research and establish research centers as a collaboration between universities and private sector.

- 27. Improving capacity of ICT departments in higher education action will provide additional academic cadre in the needed areas and develop educational models in order to ensure all undergraduate educators to have sufficient competency levels to follow-up technological developments

- 28. Improving English proficiency in ICT education action will improve the English language proficiency needed by ICT sector.

- 57. Establishing accelerator centers for Internet enterprises in universities action will support 20 universities to establish these centers and match these with technology clusters such as technoparks and R\&D centers. University students and academicians will also be encouraged to take action and work as entrepreneur or staff in these centers.

- 72. Developing Information Society Research Programme horizontal action will support related undergraduate, graduate and doctorate works, including international collaborations and capacity development for inter-disciplinary areas in natural and social sciences that set the foundation behind technological developments. A dynamic catalogue and library (physical, virtual and digital), as well as an academic journal in the related areas will also be generated and sustained. 
APPENDIX II, PROPOSED KNOWLEDGE ENGINEERING PROGRAMME CURRICULUM

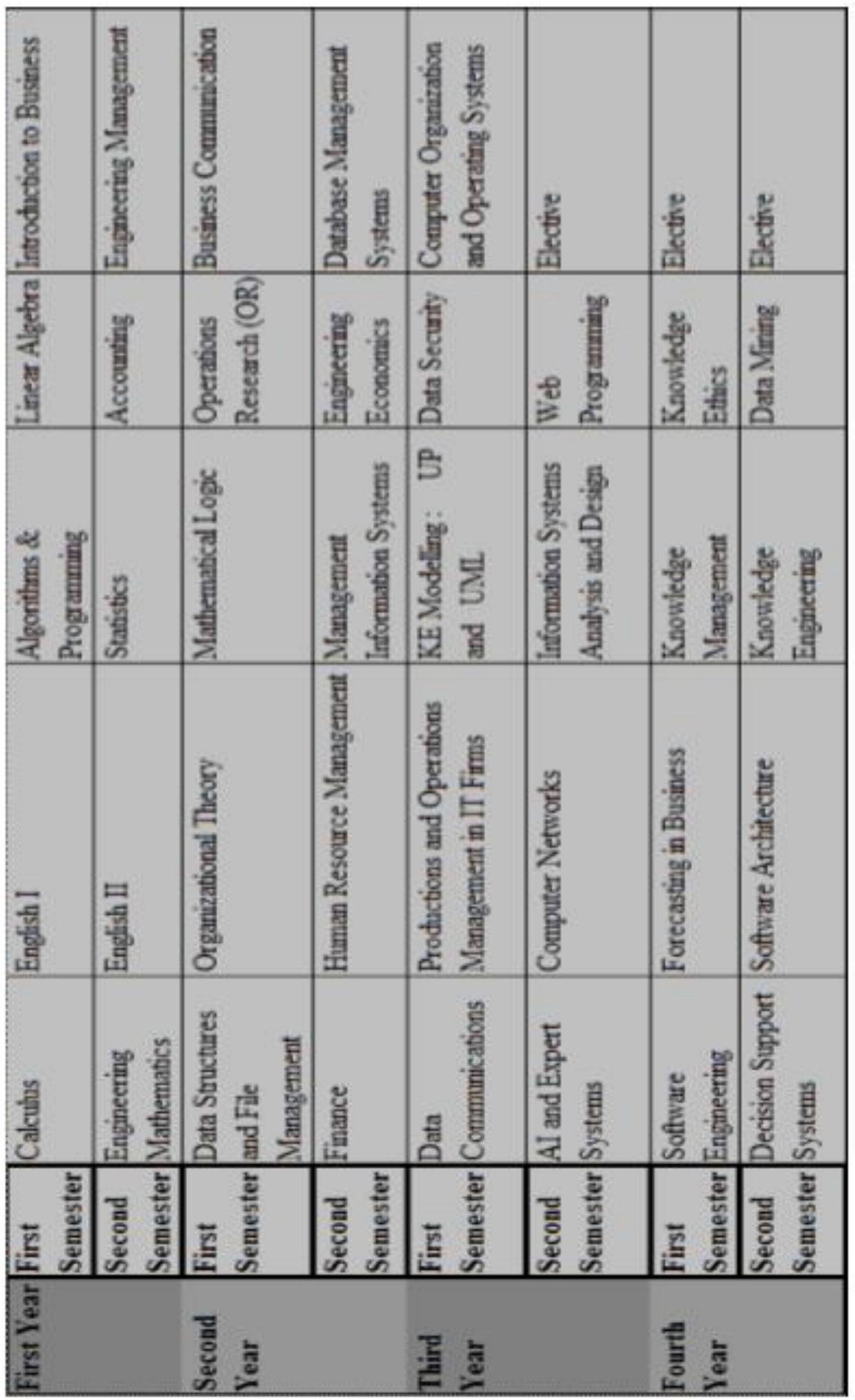

